\title{
Proceeding
}

Supplementary Issue: Winter Conferences of Sports Science. Costa Blanca Sports Science Events, 22-23 March 2021. Alicante, Spain.

\section{Resistance training for chronic low back pain in the elderly: A systematic review}

\author{
NICOLE FRITZ1', JAVIER GENE-MORALES ${ }^{2,3}$, ANGEL SAEZ-BERLANGA², ALVARO JUESAS 2,4 , JORGE \\ FLÁNDEZ ${ }^{5}$, JUAN C. COLADO ${ }^{2,4}$ \\ ${ }^{1}$ Health Department, University of Los Lagos, Puerto Montt, Chile \\ ${ }^{2}$ Research Unit in Sport and Health, University of Valencia, Valencia, Spain \\ ${ }^{3}$ Research Institute on Traffic and Road Safety (INTRAS), University of Valencia, Valencia, Spain \\ ${ }^{4}$ Department of Physical Education and Sports, University of Valencia, Valencia, Spain \\ 5 Institute of Education Sciences, Austral University of Chile, Ciudad de Valdivia, Chile
}

\begin{abstract}
Chronic low back pain is a musculoskeletal pathology with a considerably high prevalence in the elderly. This condition increases disability and negatively affects the quality of life. Muscular resistance training is being used as a cornerstone in interventions for elder people due to the numerous benefits associated with physical and functional health. For this reason, the purpose of this study was to systematically review the literature on the main characteristics of resistance training programs in the elder population with chronic low back pain. A literature search in five databases (PubMed, Scopus, Web of Science, Sports Discuss, and Cochrane Library) was carried out. Inclusion-exclusion criteria were used to select experimental studies applying resistance training programs to aging adults older than 60 ages with chronic lumbar pain. PEDro scale was used to evaluate the quality of the included studies. From the first 223 articles retrieved, 8 were selected to be further analysed. All the studies presented good methodological quality (PEDro scale from 6 to 10) and low bias risk. In summary, resistance training programs have been proven useful to significantly reduce pain and inability. Furthermore, significant improvements in quality of life and muscular strength parameters are guaranteed. Keywords: Spine; Musculoskeletal pain; Chronic low back pain; Resistance training; Older adults.
\end{abstract}

Cite this article as:

Fritz, N., Gene-Morales, J., Saez-Berlanga, A., Juesas, A., Flández, J., \& Colado, J.C. (2021). Resistance training for chronic low back pain in the elderly: A systematic review. Journal of Human Sport and Exercise, 16(3proc), S1506-S1520. https://doi.org/10.14198/ihse.2021.16.Proc3.66

Corresponding author. Department of Physical Education and Sports, University of Valencia, C/ Gascó Oliag 3, 46010 Valencia, Spain. https://orcid.org/0000-0002-3255-3940

E-mail: juan.colado@uv.es

Abstract submitted to: Winter Conferences of Sports Science. Costa Blanca Sports Science Events, 22-23 March 2021. Alicante, Spain.

JOURNAL OF HUMAN SPORT \& EXERCISE ISSN 1988-5202.

(c) Faculty of Education. University of Alicante.

doi:10.14198/jhse.2021.16.Proc3.66 


\section{INTRODUCTION}

Currently, one of the biggest concerns that are growing at the sociodemographic level is the increase in older people and the changes that are experiencing associated with this last phase of life (World Health Organization, 2016). Associated with the high aging figures, there is an increase in musculoskeletal disorders that generate pain, this is how the bibliographic review of Domenichiello and Ramsden (2019) showed that in over 65 years the high figures of chronic lumbar pain highlight alarmingly (range: 5 to $45 \%$ ) at this stage of the life cycle.

Chronic pain is a major problem for many elder people (Reid et al, 2015) and, particularly, chronic lower back pain is a very common problem that often correlates with functional limitations and difficulties in performing the activities of daily life (Aagaard et al., 2010, Lamberg, 1998; Reid et al., 2015).

International guidelines for treating chronic lower back pain in elderly people recommend nonpharmacological solutions, promoting the use of physical exercise-related therapies (Cress et al., 2005), because they increase functionality (Nelson et al., 2007) and have also shown that relieve symptoms faster, produce a reduced chronic disability, lower work absenteeism and a faster recovery rate (Tsui et al., 2010). The International Association for the Study of Pain (IASP) stressed the importance of physical therapy regimens in elderly adults because they are less "toxic" than drug therapies and also promote functional independence (Hadjistavropoulos et al., 2010).

For all of the above described chronic lower back pain in elderly adults has become a global public health problem and challenge (Katz, 2006; Mutubuki et al., 2020), which cannot be addressed following the guidelines for back pain used to treat other younger populations.

There are several exercise protocols that are recommended to stop chronic pain and, in particular, lumbar pain, however, those who develop exercises to train strength are gaining popularity (Malmivaara et al., 1995). However, although there are many approaches to special strength exercise-based therapies for middle-aged adults with lower back pain, similar programs for elderly people appear to be scarce (Singh, 2002).

Previously, in Vadalá et al. (2020) the evidence available as regards the effectiveness of the physical exercise practice to improve disability and pain in older people over 65 years old with non-specific chronic lumbar pain between 1992 and 2018 was revised, however, extreme variability in the type, duration, intensity and modality of proposed programs realization, as also the different parts of the body in which the training was focused, which made impossible to recommend a specific protocol in the old age population (Vadalá et al., 2020). The objective of this research is to make a systematic review of the literature that allows to identify and synthesize the main characteristics of muscle resistance training programs in the elderly adult population with chronic lumbar pain and as a secondary objective, describe the influence on pain, disability, and quality. It is expected this systematic review provides valuable information about the characteristics of elderly people with chronic low back pain and the different programs for resistance training to develop preventive processes and effective support.

\section{METHODOLOGY}

\section{Sources and search in literature}

A bibliographic search was carried out during January and February 2021, applying the established guidelines of the PRISMA declaration (Moher et al., 2010). Five databases were used: PubMed, Scopus, 
Web of Science, Sport Discus and Cochrane Library, from which both original English language articles, published between 1990 and 2021, were extracted.

The search strategy was designed to obtain data on the incidence of strength programs in elderly people with chronic lower back pain. For this purpose, a formulated algorithm with keywords connected through Boolean operators was used. The algorithm set was as follows: ("chronic low back pain" OR "low back pain" OR "CLBP" OR "back pain" OR "chronic pain") AND ("elderly" OR "aging" OR "older adults" OR "old people" OR "ancient" OR "aged people") AND ("resistance program" OR "strength program" OR "strength program" OR "exercise program" OR "physical activity").

\section{Selection criteria}

The search for relevant titles to the objective of this study was carried out by 3 reviewers. If there was uncertainty regarding the eligibility of a study, the summary was obtained and added to the next phase of the review for further clarification. The summaries were then selected to determine their eligibility by considering 4 key points: (a) findings related to the prevention of chronic lower back pain in the elderly through resistance training programs; (b) findings related to the incidence of pain reduction when implementing resistance training programs in older people with chronic back pain; c)findings related to the prevention of lower back pain through physical activity programs and d) findings related to the incidence of resistance training programs in the prevention of chronic lumbar pain or non-specific lower back pain.

Eligible summaries were included in the full-text recovery stage only if they fulfilled the 4 criteria described above. In the event that clarification about any of these criteria is needed, the reviewers consulted an external collaborator. Subsequently, full-text manuscripts were selected when the eligibility criteria set out in Table 1.

Table 1. Eligibility criteria for including studies in the review.

\begin{tabular}{ll}
\hline Topic & Inclusion criteria \\
\hline Participants & Older adults 60 years of age and older, with chronic low back pain. \\
Interventions & Muscular strength training. \\
Comparison & Passive or active control group with training other than strength training. \\
Outcome & Pain, disability, physical ability and/or quality of life \\
Design & Randomized clinical trials, experimental or cohort studies. \\
\hline Topic & Exclusion criteria \\
\hline Participants & Research in animals and people under 60 years of age. \\
Design & Conferences, dissertations, theses and non-peer-reviewed publications. \\
\hline
\end{tabular}

\section{Methodological quality}

The methodological quality of the studies was analysed using the "PEDro scale", validated by Maher et al. (2003). Studies with a score greater than or equal to 6 points were considered to be of high methodological quality, while a lower score was considered of low quality.

\section{RESULTS}

The characteristics of the selected articles, characteristics of the intervention, adherence, and training effects are summarized in Table 3. 
8 articles were selected, the number of studies identified and excluded can be seen in Figure 1. Initially, 223 articles from the different databases consulted were identified. Following the elimination of duplicate studies, the review of 69 articles was initiated using the selection criteria.
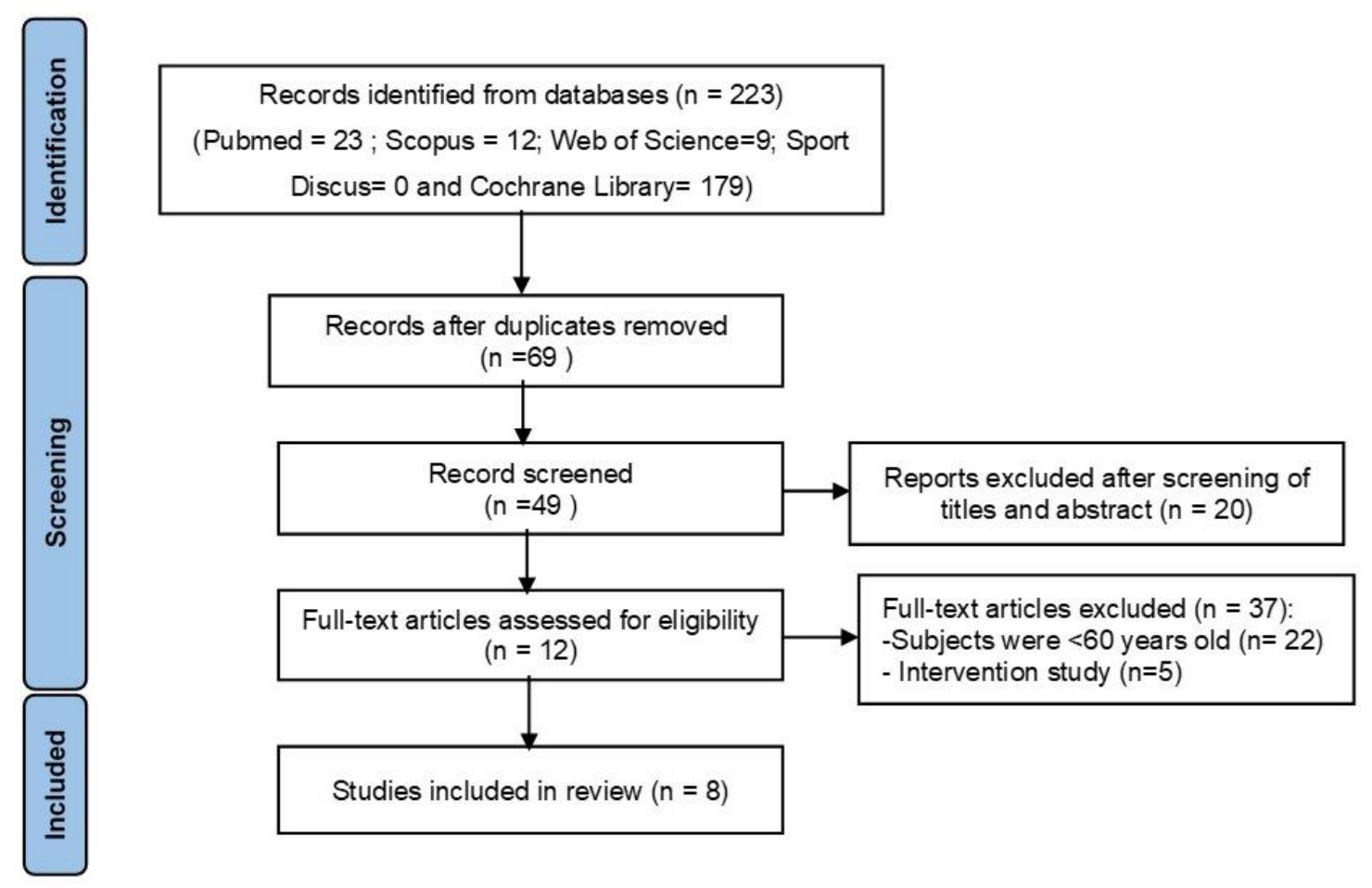

Figure 1. PRISMA flow diagram. Presentation of the procedure of literature searching and selection with numbers of articles at each stage.

\section{Characteristics of the studies}

All studies were written in English, prospective, experimental randomized clinical trials and compared training with a passive control group, which did not perform training $(n=4)$ or active conducting other forms of exercise intervention $(n=4)$.

The results of the quality assessment of each study through the PEDro scale are presented in Table 2 . The 8 selected studies were of high methodological quality and had a low risk of bias, with scores of 6 to 11 points on the PEDro scale.

All of the studies analysed included homogeneous populations of patients suffering from low back pain or chronic low back pain and only the Gatti et al. article (2011) included people who, in addition to having chronic low back pain, suffered from irradiation in one of their lower extremities. Of the 8 trials studied, 2 of them (LiuAmbrose et al., 2005; Holmes et al., 1996) had a population where they were all women and 2 of the 8 articles the population used was composed entirely of men (Jackson et al., 2011; Irandoust \& Taheri, 2015). In the remaining four review articles, the population used as a sample was composed of the two genera, that is to say, both men and women were included there.

If the monitoring time of the programs for the described resistance training in the different publications is analysed, it is observed the existence of remarkable differences between some tests and others, with periods 
in which the program does not exceed 97 days as the one from Vincent et al. (2014 a y b) and programs with more than 24 weeks like the one from Liu-Ambrose et al. (2005).

Table 2. Quality assessment of the included studies (PEDro Scale).

\begin{tabular}{|c|c|c|c|c|c|c|c|c|}
\hline PEDro Scale Item & $\begin{array}{l}\text { Holmes } \\
\text { et al., } \\
(1996)\end{array}$ & $\begin{array}{c}\text { Liu- } \\
\text { Ambrose } \\
\text { et al., } \\
(2005) \\
\end{array}$ & $\begin{array}{l}\text { Knutzen } \\
\text { et al., } \\
\text { (2007) }\end{array}$ & $\begin{array}{l}\text { Gatti } \\
\text { et al., } \\
\text { (2011) }\end{array}$ & $\begin{array}{l}\text { Jackson } \\
\text { et al, } \\
\text { (2011) }\end{array}$ & $\begin{array}{l}\text { Vincent } \\
\text { et al., } \\
\text { (2014a) }\end{array}$ & $\begin{array}{l}\text { Vincent } \\
\text { et al., } \\
\text { (2014b) }\end{array}$ & $\begin{array}{c}\text { Irandoust } \\
\text { \& Taheri } \\
(2015)\end{array}$ \\
\hline $\begin{array}{l}\text { Eligibility criteria } \\
\text { specified (Yes/No) }\end{array}$ & 1 & 1 & 1 & 1 & 1 & 1 & 1 & 1 \\
\hline Random allocation & 0 & 1 & 0 & 1 & 1 & 1 & 1 & 1 \\
\hline $\begin{array}{l}\text { Concealed } \\
\text { allocation }\end{array}$ & 0 & 1 & 0 & 1 & 1 & 1 & 1 & 1 \\
\hline $\begin{array}{l}\text { Comparable at } \\
\text { baseline }\end{array}$ & 1 & 1 & 1 & 1 & 1 & 1 & 1 & 1 \\
\hline Blind subjects & 0 & 1 & 0 & 1 & 1 & 1 & 1 & 1 \\
\hline Bind therapist & 0 & 1 & 1 & 1 & 1 & 1 & 1 & 1 \\
\hline Blind assessors & 0 & 1 & 1 & 1 & 1 & 1 & 1 & 1 \\
\hline Adequate follow-up & 1 & 1 & 1 & 1 & 1 & 1 & 1 & 1 \\
\hline $\begin{array}{l}\text { Intention-to-treat } \\
\text { analysis }\end{array}$ & 1 & 1 & 1 & 1 & 1 & 1 & 1 & 1 \\
\hline $\begin{array}{l}\text { Between-group } \\
\text { comparison }\end{array}$ & 1 & 1 & 1 & 1 & 1 & 1 & 1 & 1 \\
\hline $\begin{array}{l}\text { Point estimates and } \\
\text { variability }\end{array}$ & 1 & 1 & 1 & 1 & 1 & 1 & 1 & 1 \\
\hline $\begin{array}{l}\text { PEDro total score } \\
(0-10)\end{array}$ & 6 & 11 & 8 & 11 & 11 & 11 & 11 & 11 \\
\hline
\end{tabular}

The establishing of a determined time to consider the low back pain as "chronic" also changed from some authors to others, 2 of the articles included in their sample to patients who suffered from chronic low back pain for more than three months (Gatti et al, 2011; Jackson et al., 2011). In 2 articles, the inclusion of people with chronic low back pain was as of six months (Vincent et al., 2014a y b). However, other authors did not establish a specific time of chronic lumbar pain suffered by the participant (Holmes et al., 1996; Irandoust \& Taheri, 2015; Knutzen et al., 2007; Liu-Ambrose et al., 2005).

Six of the nine articles compare the effectiveness of resistance programs against control groups that do not practice any physical exercise. It was possible to observe how the results obtained in them were significantly favourable to the strength exercises (Table 3).

The programs for the resistance training based on the global training of the whole body are present in seven of the eight studied articles, the Holmes study et al. (1996) resulted in being the only exclusive program of isolated lumbar extension in Medxmachine. From the studies analysed tests can be extracted where the effectiveness of the programs for the resistance training is compared to another kind of program related to the physical exercise, it was found the resistance training program against stabilization exercises from Gatti et al. (2011) and agility and flexibility compared to a program for the strength and flexibility training (LiuAmbrose et al., 2005). 
Table 3. Summary of articles selected for review.

\begin{tabular}{|c|c|c|c|c|c|c|c|}
\hline Author & Design & Population & $\begin{array}{l}\text { Comparison } \\
\text { group }\end{array}$ & $\begin{array}{l}\text { Intervention } \\
\text { time }\end{array}$ & Evaluations & $\begin{array}{l}\text { Intervention Strength } \\
\text { Program }\end{array}$ & Outcomes \\
\hline $\begin{array}{l}\text { Holmes } \\
\text { et al., } \\
(1996)\end{array}$ & Prospective & $\begin{array}{l}\mathrm{n}=38 \text { women } \\
20 \text { healthy } \\
\text { and } 18 \text { with } \\
\mathrm{CLBP} \text {; } \\
\text { age }=68.3 \pm 6.6 \\
\text { years }\end{array}$ & $\begin{array}{l}\text { Strength } \\
\text { training } \\
\text { versus non- } \\
\text { intervention } \\
\text { control }\end{array}$ & 97 days & $\begin{array}{l}\text { Pain: VAS } \\
\text { Strength: } \\
\text { lumbar } \\
\text { extension }\end{array}$ & $\begin{array}{l}\text { Mode: isotonic lumbar } \\
\text { flexion-extension cycles } \\
3-4 \text { s per phase. } \\
\text { Intensity: } 2 \text { minutes, a } \\
\text { total of } 20 \text { repetitions } \\
\text { the first } 4 \text { weeks, the } \\
\text { following sessions with } \\
\text { repetitions until muscle } \\
\text { fatigue. } \\
\text { Frequency: twice a } \\
\text { week the first } 4 \text { weeks } \\
\text { and the following } \\
\text { sessions, eleven times } \\
\text { a week. }\end{array}$ & $\begin{array}{l}\downarrow \text { Pain: } \downarrow 60 \% \text { (pre } 5.3 \\
\text { and pos } 2.1 \text { point, } \\
\text { p<0.05) } \\
\uparrow \text { Strength: } \uparrow 71 \%\end{array}$ \\
\hline $\begin{array}{l}\text { Liu- } \\
\text { Ambrose } \\
\text { et al., } \\
(2005)\end{array}$ & Prospective & $\begin{array}{l}\mathrm{n}=98 \text { women } \\
\text { with } \mathrm{CLBP} ; \\
\text { age }=79 \pm 3 \\
\text { years }\end{array}$ & $\begin{array}{l}3 \text { exercise } \\
\text { programs: } 1 . \\
\text { strength, } 2 . \\
\text { agility, and } 3 . \\
\text { stretching. }\end{array}$ & 25 weeks & $\begin{array}{l}\text { Pain: VAS } \\
\text { Quality of life: } \\
\text { QUALEFFO } \\
\text { Disability: } \\
\text { ODQ }\end{array}$ & $\begin{array}{l}\text { Mode: progressive and } \\
\text { high intensity with } 8 \\
\text { exercises for the major } \\
\text { muscle groups. } \\
\text { Intensity: initially at } 50- \\
60 \% \text { of } 1 \text { RM with } 2 \text { sets } \\
\text { of } 10-15 \text { repetitions and } \\
\text { progressed to } 75 \text { to } \\
85 \% \text { of } 1 \text { RM in a work } \\
\text { range of } 2 \text { sets of } 6-8 \\
\text { repetitions by week } 4 \text {. } \\
\text { Frequency: once a } \\
\text { week, } 50 \text { minutes per } \\
\text { session. }\end{array}$ & $\begin{array}{l}\downarrow \text { Pain: } \downarrow 27 \% \text { ( } p= \\
0.01 \text { ). Disability: no } \\
\text { significant between- } \\
\text { group differences. } \\
\uparrow \text { Quality of life : } \\
\uparrow 10 \% \text { quality of life and } \\
\uparrow 33 \% \text { in the pain } \\
\text { domain ( } p=0.03 \text { ). }\end{array}$ \\
\hline
\end{tabular}

Mode: progressive from

moderate to high

intensity with 11 exercises focused on the lower extremity.

$\mathrm{n}=97$

participants Strength

Knutzen with CLBP; training

et al., Prospective 57 women y versus non-

(2007)

40 men; age:

60 a 83 control

years;
8 weeks $\quad$ Pain: MPQ

Intensity: initially at

$50 \%$ of $1 \mathrm{RM}$ until the

second week of

training, progressively

increasing to $80 \%$ in the

fifth week, working at

$80 \%$ until the end of the

program, 3 sets of $7-10$

repetitions maximum

per exercise.

Frequency: three times

a week

Mode: 4 strength

exercises (abdominal

$\begin{array}{lllll} & & n=79 \text { con } & & \\ \text { Gatti et } & \text { CLBP 28 men } & \text { Trunk } & & \\ \text { sal., } & \text { stabilization } & & \text { Pain: VAS } \\ \text { (2011) } & \text { Prospective } 51 & \text { women; age: } & \text { training } & \text { Quality of life: } \\ \text { PEDro: } & \text { versus } & \text { 5 weeks } & \text { SF-12 } \\ \text { 11/11 } & \text { (32,8 years } 85 & \text { strength } & & \text { Disability: } \\ & \text { years) } & \text { training } & \text { RMD } \\ & & & \end{array}$

crunch, knee extension

femoral curl and

shoulder extension on

machine)

3 sets of 8 repetitions.

Frequency: twice a

week, 60 minutes per

session.
Intensity: $50 \%$ of $1 \mathrm{RM}$, $\downarrow$ Pain: $\downarrow 50 \%$. Significant difference in four of the eight pain measures, including overall perceived pain intensity $(p \leq 0.02)$, sensory aspects of pain $(p \leq 0.06)$, pain qualities $(p \leq 0.05)$, and number of words chosen for qualitative pain assessment $(p \leq$ 0.04). $\downarrow$ Pain: $\downarrow 60 \%$ (pre 5.3

and pos 2.1 point,

0.01). Disability: no $\downarrow$ Pain: $5.6 \pm 26.9 \mathrm{~mm}$ $(p=0.115)$

$\downarrow$ Disability: $\downarrow 3.2$

points $(p=0.005)$

$\uparrow$ Quality of life: $\uparrow 2.3$

points $(p=0.032)$ 


\begin{tabular}{|c|c|c|c|c|c|c|c|}
\hline $\begin{array}{l}\text { Jackson } \\
\text { et al, } \\
(2011)\end{array}$ & Prospective & $\begin{array}{l}\mathrm{n}=45 \text { men } \\
\text { with CLBP; } \\
\text { age: }>50 \\
\text { years } \\
\text { (includes an } \\
\text { elderly group } \\
>60 \text { years) }\end{array}$ & $\begin{array}{l}3 \text { age } \\
\text { groups: } \\
\text { median age } \\
52 \pm 2.7 \\
\text { years, older } \\
\text { age } 63 \pm 3.1 \\
\text { years and } \\
\text { control } \\
57 \pm 7.7 \text { years } \\
\text { without } \\
\text { intervention }\end{array}$ & 16 weeks & $\begin{array}{l}\text { Pain: VAS } \\
\text { Disability: } \\
\text { ODI Quality of } \\
\text { Life: SF-36 } \\
\text { Global } \\
\text { muscle } \\
\text { strength }\end{array}$ & $\begin{array}{l}\text { Mode: progressive } \\
\text { program from low to } \\
\text { moderate intensity, } 12 \\
\text { strength exercises for } \\
\text { the major muscle } \\
\text { groups. } \\
\text { Intensity: } 55-60 \% \text { of } \\
1 \text { RM the first } 3 \text { weeks } \\
\text { and then } 60-83 \% \text { of } \\
1 \text { RM, } 3 \text { to } 6 \text { sets of } 5 \\
\text { repetitions. } \\
\text { Frequency: four times } \\
\text { a week. }\end{array}$ & $\begin{array}{l}\downarrow \text { Pain: significant } \\
\text { intragroup and versus } \\
\text { the control group, with } \\
\text { no differences between } \\
\text { the middle-aged and } \\
\text { elderly groups. The } \\
\text { greatest improvements } \\
\text { were for the middle- } \\
\text { aged group. } \\
\uparrow M u s c l e ~ s t r e n g t h: \\
\uparrow 25 \% \text { in strength in the } \\
\text { advanced age group, } \\
\text { significantly ( } p \leq 0.05 \text { ). }\end{array}$ \\
\hline $\begin{array}{l}\text { Vincent et } \\
\text { al., } \\
(2014 a)\end{array}$ & Prospective & $\begin{array}{l}\mathrm{n}=49 \\
\text { participants } \\
\text { with CLBP } \\
\text { and BMl } \\
\geq 30 \mathrm{~kg} / \mathrm{m} 2 \\
19 \text { men and } \\
30 \text { women; } \\
\text { age: } 60 \text { to } \\
85 \text { years. }\end{array}$ & \multirow[t]{2}{*}{$\begin{array}{l}3 \text { groups: } \\
\text { Global } \\
\text { strength } \\
\text { training } \\
\text { versus } \\
\text { strengthening } \\
\text { through } \\
\text { lumbar } \\
\text { extension } \\
\text { and a control } \\
\text { group under } \\
\text { education. }\end{array}$} & \multirow[t]{2}{*}{4 months } & $\begin{array}{l}\text { Pain: NRS } \\
\text { Scale } \\
\text { Catastrophism: } \\
\text { PCS } \\
\text { Strength and } \\
\text { mobility: } \\
\text { Walking Tests } \\
\text { and Strength }\end{array}$ & \multirow{2}{*}{$\begin{array}{l}\text { Global strength } \\
\text { training group. } \\
\text { Mode: } 12 \text { exercises of } \\
\text { the major muscle groups } \\
\text { Intensity: } 60 \% \text { of } 1 \mathrm{RM} \text {, } \\
15 \text { repetitions increasing } \\
\text { the load by } 2 \% \text { per } \\
\text { week. Frequency: } 3 \\
\text { sessions per week. } \\
\text { Lumbar extension } \\
\text { training group. } \\
\text { Mode: isolated lumbar } \\
\text { extension. } \\
\text { Intensity: } 60 \% \text { of } 1 \mathrm{RM} \\
\text { and increased by } \\
\text { approximately } 2 \% \text { per } \\
\text { week, } 15 \text { repetitions } \\
\text { Frequency: once a } \\
\text { week for the first } 2 \\
\text { weeks and then three } \\
\text { times a week. }\end{array}$} & $\begin{array}{l}\downarrow \text { Pain: significant when } \\
\text { getting up from a chair in } \\
\text { the global training group } \\
\text { and significant when } \\
\text { walking for both training } \\
\text { groups. } \\
\downarrow \text { Catastrophism: global } \\
\text { strength training group } \\
\text { significant intragroup } \\
\text { improvement and greater } \\
\text { than global extension. } \\
\uparrow \text { Strength: } \uparrow 20 \% \text { spinal } \\
\text { extensor strength and } \\
\text { non-significant } \\
\text { improvement in Walking } \\
\text { Tests. }\end{array}$ \\
\hline $\begin{array}{l}\text { Vincent } \\
\text { et al., } \\
\text { (2014b) }\end{array}$ & Prospective & $\begin{array}{l}n=49 \\
\text { participants } \\
\text { with CLBP } \\
19 \text { men and } \\
30 \text { women } \\
\text { age: } 60 \text { to } \\
85 \text { years old }\end{array}$ & & & $\begin{array}{l}\text { Disability: ODI } \\
\text { and RMD }\end{array}$ & & $\begin{array}{l}\downarrow \text { Pain: was significant } \\
\text { and greater in the global } \\
\text { strength training group. }\end{array}$ \\
\hline $\begin{array}{l}\text { Irandoust } \\
\text { \& Taheri } \\
(2015)\end{array}$ & Prospective & $\begin{array}{l}\mathrm{n}=32 \text { men } \\
\text { with CLBP; } \\
\text { age: } \\
68.4 \pm 2.9 \\
\text { years }\end{array}$ & $\begin{array}{l}\text { Aquatic } \\
\text { strength } \\
\text { training } \\
\text { versus non- } \\
\text { intervention } \\
\text { control group }\end{array}$ & 12 weeks & $\begin{array}{l}\text { Pain: SBST } \\
\text { Body } \\
\text { composition: } \\
\text { BMl and trunk } \\
\text { muscular mass }\end{array}$ & $\begin{array}{l}\text { Mode: program with } 9 \\
\text { exercises for the major } \\
\text { muscle groups and } \\
\text { water aerobic exercise. } \\
\text { Intensity: } 60 \text { min at } 50 \text { - } \\
70 \% \text { HRmax } \\
\text { Frequency: three times } \\
\text { a week, } 1 \text { strength } \\
\text { session per week and } \\
\text { twice a week of water } \\
\text { aerobic exercise, } 60 \\
\text { minutes per session. }\end{array}$ & $\begin{array}{l}\downarrow \text { Pain: was significant } \\
\text { and greater in the global } \\
\text { strength training group. } \\
\text { Trunk muscle mass by } \\
4.1 \% \text {. }\end{array}$ \\
\hline
\end{tabular}

Abbreviations: BMI: body mass index; CLBP: Chronic lumbar back pain; HR max: heart: maximal heart rate; MPQ: Mc Gill Pain Questionnaire; NRS: numeric rating scale; ODI: Oswestry disability index; PCS: pain catastrophizing scale; QUALEFFO: Quality of Life Questionnaire; RMD: Roland Morris Disability; SF-12: 12-Item Short-Form Health Survey; SF-36: Short Form-36 Health Survey; SBST: STarT back screening tool; VAS: visual analogue scale.

\section{Procedure results}

As regards the results obtained after the procedure, in all the studies the reports show a significant improvement in the pain parameters while depending on the analysed study variables they report significant improvements in muscular strength parameters (Holmes et al., 1996; Jackson et al., 2011), disability (Gatti et al., 2011) and quality of life (Liu-Ambrose et al., 2005; Gatti et al., 2011), catastrophism (Vincent et al., 2014a) and increase in the trunk muscular mass (Irandoust \& Taheri, 2015) (Table 2). 


\section{DISCUSSION}

The objective of this bibliographic review was to describe the main characteristics of the muscular resistance training programs in the elderly adult population with chronic lumbar pain and the influence on the pin, incapacity, and quality of life the programs for the strength training applied to old people with chronic low back pain, disability, and quality. Under this premise and after analysing the obtained data, it was possible to see heterogeneity in the characteristics of the training programs, however, in all cases in which a strength periodic training was made, better results were obtained in those programs in which another type of physical activity or exercise was made.

During periods of pain and discomfort, people use to protect or take care of movements related to the damaged part (Graves et al., 1994). This protection, because of fear, produces body muscular atrophy, which at the same time makes the muscles weak. Weakness is a previous effect of muscular failure which is caused by the harmful stimuli which come from the suffered pain. This condition, if it exceeds in time, results in a well-known process as chronic deconditioning syndrome (Smith et al., 2011). That is the reason why effective training should prevent the continuity in this syndrome (Flicker et al., 1993).

The periodized programs for the strength training are presented as one of the most effective methods for the rehabilitation of people with chronic lower back pain, since they produce the development of the muscleskeletal health, improving significantly the corporal composition, resulting in a decrease of pain and disability and increasing, in this way, the quality of life in people who practice them (Marcell, 2003). That is how strength training in elderly people improves neuromuscular control, bone mineral density, muscles, strength, and functional capacities (Jackson et al., 2011; Kell \& Asmundson, 2009). The strength advantages are produced in the first 8 weeks of training, they are associated with the neurological adjustments, motor coordination, and the synchronicity of the motor unities. Strength improvements after the first 8 weeks are generally related to the increase of muscle anabolism or hypertrophy (Häkkinen et al., 2005). The overloading stimulus demands the involved muscles work with a superior intensity in relation to the typical levels. Moreover, it improves neural control and increases the size of the contractile muscle protein (Goldberg et al., 1975). The muscle tissue adapts itself physiologically to the stimuli levels, obtaining strength advantages through the neural control facilitation and the muscle hypertrophy (Moritani \& DeVries, 1979). The mechanic charge also helps the connective tissue rearrangement during the reparation process. In addition to this, the levels of muscle strength are important in older people with chronic low back pain since the highest levels of strength have a protective effect on the appearance of new lumbar pain episodes (Taylor et al., 2014) and in the same way, the strength exercises reduce the risk of lumbar pain appearance (Schild von Spannenberg et al., 2012).

Besides, scientific evidence has shown that exercise itself has an analgesic effect following exercise, the most commonly tested hypothesis to explain this effect being the activation of the endogenous opioid system. (Koltyn, 2002; Koltyn \& Arbogast, 1998.) This theory establishes that exercise results in a release of hypothalamus endorphins and the brain pituitary regions. These endorphins work central and peripheral to activate the same receptors in which opioid medication works (Ugur et al., 2018). Analgesia after exercise seems to be more consistent when the exercise stimulus requires intensity over $70 \%$ (Koltyn, 2002; Koltyn \& Arbogast, 1998), which is concordant with the training intensity reached by the training programs included in this systematic review. Previous studies where this analgesic effect has been proven include the study by Koltyn and Arbogast who examined the analgesic effect of a 45-minute muscle strength training session at moderate-high intensity ( 3 sets of 10 repetitions at $75 \%$ of $1 \mathrm{RM}$ ) versus a control group with no exercise. Showing that the pain thresholds increased significantly 5 minutes after the against resistance exercise, with an analgesic effect that lasted from 15 to 20 minutes for the following exercise. After the analysis, it was also 
possible to show that the pain indices were lower 5 minutes after the resistance exercise, and to this was added the observation of changes in blood pressure and heart rate after exercise.

Therefore, and based on the evidence found in this literature review, we must emphasize with regard to the appropriate duration from which benefits could be obtained during the application of a periodized program for strength training that, as a minimum, in order to begin to obtain such adaptations, programs should have a duration of more than 8 weeks. This duration fully corresponds to the programs proposed by the different authors mentioned above, from which significant gains in strength can be observed, as well as a reduction in pain and disability in the people who performed this type of training.

Hodges (2011) It was explained that one of the factors for muscle weakness in people with low back pain may be due to delayed trunk muscle activation, with an emphasis on the transverse abdominal and multifidus muscles. This delayed activation has been described as a significant impairment of the neural control unit of the trunk stabilizer system. The functional consequence of delayed response of the trunk muscles to sudden external loads is a deficit in trunk stability (Moseley \& Hodges, 2005). Balance deficits in individuals with chronic low back pain have been demonstrated through the increased displacement of the centre of pressures while standing and performing mediolateral postures (Hibbs et al., 2008). For this reason, in some training programs, it is suggested to work with exercises focused on postural rebalancing (Standaert et al., 2004). These exercises, which also include the strengthening of the trunk muscles, are performed in unstable conditions and are usually included in the rehabilitation protocols using the concept of strengthening the Core (Akuthota \& Nadler, 2004; Calatayud et al., 2015; Calatayud et al., 2017). However, in the Gatti et al. (2011) study it was shown that there was no significant difference in pain reduction between a stabilization program and a strength training program, but that stabilization exercises do have a positive impact on reducing disability and increasing mobility in everyday situations such as climbing stairs or getting in and out of a chair.

On the other hand, it is worth mentioning that there are other types of exercise modalities to take into account. These are strength exercises applied in the aquatic environment, using this resource as the resistance itself, as well as being complementary and, if so desired, relaxing, as they could reduce the tension on the affected muscles and joints (Hayden et al., 2005). In addition, the combination of buoyancy and resistance properties could allow the application of less stressful exercise modalities for this type of population (Kargarfard et al., 2013; Simmons \& Hansen, 1996).

In the Irandoust \& Taheri (2015) study which evaluated the influence of aquatic exercise on body composition and low back pain in elderly men, significant improvements in body mass index, trunk muscle mass, and decrease in low back pain were observed after 12 weeks of treatment. It has been established that obesity or overweight has negative effects on the lower back (Shir et al., 2010), one of the reasons for the decrease in low back pain may be related to the change in body composition of the individual. In line with the findings of other studies, an improvement in low back pain after aquatic exercise therapy has been demonstrated (Dundar et al., 2009; Maher, 2004; Urquhart et al., 2011).

As mentioned above, weakness in the abdominal and lumbar musculature is considered one of the main reasons for chronic low back pain in elderly adults; therefore, increasing muscle volume and strength may be an effective strategy in the treatment of these symptoms (Bo Andersen et al., 2006; Verna et al., 2002). In this particular case the trunk musculature has improved by up to $4.1 \%$ after 12 weeks of aquatic training (Irandoust \& Taheri, 2015). As with global periodized training, the effectiveness of this type of program lies in the fact that both upper and lower body parts can be involved in the work, but in this case, the level of stress suffered by individuals is greatly reduced. 
It seems that periodized programs that train strength in a global manner provide different benefits in elderly people with chronic low back pain, such as improvements in coordination, balance and flexibility, as well as, specifically with the main objectives of this review, increased levels of muscle strength, which reduces the levels of pain reported; changes in body composition are produced, which translates into improved motor function and significant improvements in people's quality of life (Maul et al., 2005). But it should not be forgotten that because during the execution of any resistance exercise, it is possible to put anatomical structures at risk with certain body positions, it is essential to work on the technique of the movements to avoid injuries (Colado \& García-Massó, 2009).

After comparing the intervention programs used by the studies reviewed in this research, their effectiveness seems to be based on three fundamental aspects. Firstly, in providing a global training of the whole body, with emphasis on the large muscle groups, to improve the overall health of the musculoskeletal system and consequently improve people's physical functionality. Secondly, in the choice of a traditional periodized program. The main differences between periodized and non-periodized programs are the alternating load plans (8-10 and 12-15RM) on successive workouts, whereas a simple progressive overload program uses a traditional moderate-intensity load plan (10RM) with a constant relative intensity (Kraemer et al., 2003) . Another key factor in the effectiveness of these programs is that for elderly people with chronic low back pain, after a familiarization phase, the volume should be increased gradually, as well as the intensity, substantially reducing the volume later, while the intensity should likewise be increased. Periodization strength training studies have generally implemented a 3-day-a-week training program, but the progressive program approach uses a 4-day-a-week periodization. This decision is based on previous research which suggests that 4 days/week training would effectively build strength in people with back pain (Kell \& Asmundson, 2009).

It should be considered that the inclusion of free weights exercises is one of the most important features of this type of program. Free weight exercises are associated with greater work of the synergist and stabilizer muscles, as they are generally considered more neurologically complex and demanding than exercises performed on machines (Charette et al., 1991). The reason for the increased activation of these muscle groups is the increased neuromuscular control needed to execute the proper movement with free weights. Neural complexity, associated with increasing the free weight component in global periodized programs, results in an increase in muscle strength development (Spennewyn, 2008). Free weight exercises focus on the primary muscles but working the synergist and stabilizer muscles in line with the primary muscles are important for improving pain symptoms in people with chronic low back pain (Hartigan et al., 2000).

Finally, progressive global resistance training programs have shown more significant improvements in pain, disability, and quality of life in patients with chronic low back pain compared to other types of training programs. The study by Jackson et al. (2011) further demonstrated that the percentage change in the strength of the primary muscles of the upper limbs (in the bench press) and lower limbs (leg press) correlated with both pain $(+0.80,+0.71$, respectively) and disability $(+0.78,+0.72$, respectively). Therefore, it is important to highlight that the results indicate that changes in the strength can be used to predict changes in pain and disability and that the prediction can be made with both upper and lower limb exercises.

The main limitation of this work has been the limited number of specific publications on the subject. There are very limited articles that meet the three requirements we were looking for in this review: resistance programs, elderly people and chronic low back pain, thus further research is needed to deepen the knowledge of strength training programs that help to reduce pain, disability and quality of life in elderly people with chronic low back pain. 


\section{CONCLUSIONS}

Global and periodized resistance training are more effective than other types of non-periodized physical activity programs for elderly people suffering from chronic low back pain, as it has produced significant gains in terms of reduction of pain, disability, or incapacity and improvements in the quality of life of the people who have undergone it and, in addition, it has also provided significant improvements in muscle strength parameters.

The training program that can be recommended, following the literature review, is a minimum duration of 8 weeks to allow the relevant neuromuscular adaptations to develop, with an adaptation or familiarization phase of 2-4 weeks. After this phase, training will begin 3 to 4 days/week, alternating polyarticular exercises at the beginning of the session and monoarticular exercises at the end of it. The exercises will be global, as mentioned above, therefore working the muscles of both the lower and upper limbs and then moving on to the secondary or smaller muscle groups later. Starting with intensities of $55-60 \%$ of $1 \mathrm{RM}$ is recommended to gradually reach an intensity of $70-80 \%$ of $1 \mathrm{RM}$, including 8-11 exercises per session and 10RM per exercise, with a rest of 1-2 minutes between sets and exercises and a total of 3-6 sets per session.

\section{REFERENCES}

Aagaard, P., Suetta, C., Caserotti, P., Magnusson, S. P., \& Kjaer, M. (2010). Role of the nervous system in sarcopenia and muscle atrophy with aging: strength training as a countermeasure. Scand J Med Sci Spor, 20(1), 49-64. https://doi.org/10.1111/j.1600-0838.2009.01084.x

Akuthota, V., \& Nadler, S. F. (2004). Core strengthening. Arch Phys Med Rehabil 85, 86-92. https://doi.org/10.1053/i.apmr.2003.12.005

Apel, J. M., Lacey, R. M., \& Kell, R. T. (2011). A Comparison of Traditional and Weekly Undulating Periodized Strength Training Programs with Total Volume and Intensity Equated. J Strength Cond Res, 25(3), 694-703. https://doi.org/10.1519/jsc.0b013e3181c69ef6

Bo Andersen, L., Wedderkopp, N., \& Leboeuf-Yde, C. (2006). Association Between Back Pain and Physical Fitness in Adolescents. Spine, 31(15), 1740-1744. https://doi.org/10.1097/01.brs.0000224186.68017.e0

Calatayud, J., Borreani, S., Martin, J., Martin, F., Flandez, J., \& Colado, J. C. (2015). Core muscle activity in a series of balance exercises with different stability conditions. Gait Posture, 42(2), 186-192. https://doi.org/10.1016/i.gaitpost.2015.05.008

Calatayud, J., Casaña, J., Martín, F., Jakobsen, M. D., Colado, J. C., \& Andersen, L. L. (2017). Progression of Core Stability Exercises Based on the Extent of Muscle Activity. Am J Phys Med Rehabil, 96 (10), 694-699. https://doi.org/10.1097/phm.0000000000000713

Charette, S. L., McEvoy, L., Pyka, G., Snow-Harter, C., Guido, D., Wiswell, R. A., \& Marcus, R. (1991). Muscle hypertrophy response to resistance training in older women. J Appl Physiol, 70(5), 19121916. https://doi.org/10.1152/jappl.1991.70.5.1912

Colado, J. C., \& García-Massó, X. (2009). Technique and Safety Aspects of Resistance Exercises: A Systematic Review of the Literature. Phys Sportsmed, 37(2), 104-111. https://doi.org/10.3810/psm.2009.06.1716

Cress, M. E., Buchner, D. M., Prohaska, T., Rimmer, J., Brown, M., Macera, C., DiPietro, L., \& ChodzkoZajko, W. (2005). Best Practices for Physical Activity Programs and Behavior Counseling in Older Adult Populations. J Aging Phys Act, 13(1), 61-74. https://doi.org/10.1123/japa.13.1.61

Domenichiello, A. F., \& Ramsden, C. E. (2019). The silent epidemic of chronic pain in older adults. Prog Neuropsychopharmacol Biol Psychiatry, 93, 284-290. https://doi.org/10.1016/j.pnpbp.2019.04.006 
Dundar, U., Solak, O., Yigit, I., Evcik, D., \& Kavuncu, V. (2009). Clinical Effectiveness of Aquatic Exercise to Treat Chronic Low Back Pain. Spine, 34(14), 1436-1440. https://doi.org/10.1097/brs.0b013e3181a79618

Flicker, P. L., Fleckenstein, J. L., Ferry, K., Payne, J., Ward, C., Mayer, T., Parkey, R. W., \& Peshock, R. M. (1993). Lumbar Muscle Usage in Chronic Low Back Pain. Spine, 18(5), 582-586. https://doi.org/10.1097/00007632-199304000-00010

Gatti, R., Faccendini, S., Tettamanti, A., Barbero, M., Balestri, A., \& Calori, G. (2011). Efficacy of Trunk Balance Exercises for Individuals With Chronic Low Back Pain: A Randomized Clinical Trial. J Orthop Sports Phys Ther, 41(8), 542-552. https://doi.org/10.2519/jospt.2011.3413

Goldberg, A. L., Etlinger, J. D., Goldspink, D. F., \& Jablecki, C. (1975). Mechanism of work-induced hypertrophy of skeletal muscle. Med Sci Sports, 7(3), 185-198. https://doi.org/10.1249/00005768197500730-00016

Graves, J. E., Webb, D. C., Pollock, M. L., Matkozich, J., Leggett, S. H., Carpenter, D. M., Foster, D. N., \& Cirulli, J. (1994). Pelvic stabilization during resistance training: Its effect on the development of lumbar extension strength. Arch Phys Med Rehabil, 75(2), 210-215. https://doi.org/10.1016/00039993(94)90398-0

Hadjistavropoulos, T., Fitzgerald, T. D., \& Marchildon, G. P. (2010). Practice Guidelines for Assessing Pain in Older Persons with Dementia Residing in Long-Term Care Facilities. Physiother Can, 62(2), 104-113. https://doi.org/10.3138/physio.62.2.104

Häkkinen, K., Kallinen, M., Izquierdo, M., Jokelainen, K., Lassila, H., Mälkiä, E., Kraemer, W. J., Newton, R. U., \& Alen, M. (1998). Changes in agonist-antagonistEMG, muscle CSA, and force during strength training in middle-aged and older people. J Appl Physiol, 84(4), 1341-1349. https://doi.org/10.1152/jappl.1998.84.4.1341

Hartigan, C., Rainville, J., Sobel, J. B., \& Hipona, M. (2000). Long-term exercise adherence after intensive rehabilitation for chronic low back pain. Med Sci Sports Exerc, 32(3), 551-557. https://doi.org/10.1097/00005768-200003000-00001

Hayden, J. A., van Tulder, M. W., \& Tomlinson, G. (2005). Systematic Review: Strategies for Using Exercise Therapy To Improve Outcomes in Chronic Low Back Pain. Ann Intern Med, 142(9), 776. https://doi.org/10.7326/0003-4819-142-9-200505030-00014

Hibbs, A. E., Thompson, K. G., French, D., Wrigley, A., \& Spears, I. (2008). Optimizing Performance by Improving Core Stability and Core Strength. Sports Med, 38(12), 995-1008. https://doi.org/10.2165/00007256-200838120-00004

Hodges, P. W. (2011). Pain and motor control: From the laboratory to rehabilitation. Journal of Electromyography and Kinesiology, 21(2), 220-228. https://doi.org/10.1016/j.jelekin.2011.01.002

Holmes, B., Leggett, S., Mooney, V., Nichols, J., Negri, S., \& Hoeyberghs, A. (1996a). Comparison of Female Geriatric Lumbar-Extension Strength. J Electromyogr Kinesiol, 9(1), 17???22. https://doi.org/10.1097/00002517-199602000-00003

Irandoust, K., \& Taheri, M. (2015). The effects of aquatic exercise on body composition and nonspecific low back pain in elderly males. J Phys Ther Sci, 27(2), 433-435. https://doi.org/10.1589/pts.27.433

Iversen, M. D., Fossel, A. H., \& Katz, J. N. (2003). Enhancing function in older adults with chronic low back pain: a pilot study of endurance training. Arch Phys Med Rehabil, 84(9), 1324-1331. https://doi.org/10.1016/s0003-9993(03)00198-9

Jackson, J. K., Shepherd, T. R., \& Kell, R. T. (2011a). The Influence of Periodized Resistance Training on Recreationally Active Males with Chronic Nonspecific Low Back Pain. J Strength Cond Res, 25(1), 242-251. https://doi.org/10.1519/jsc.0b013e3181b2c83d

Kargarfard, M., Dehghadani, M, M., \& Ghias, R. (2013). The Effect of Aquatic Exercise Therapy on Muscle Strength and Joint's Range of Motion in Hemophilia Patients. Int J Prev Med, 4(1), 50-56. 
Katz, R. T. (2001). Impairment and Disability Rating in Low Back Pain. Phys Med Rehabil Clin N Am, 12(3), 681-694. https://doi.org/10.1016/s1047-9651(18)30060-3

Kell, R. T., \& Asmundson, G. J. G. (2009). A Comparison of Two Forms of Periodized Exercise Rehabilitation Programs in the Management of Chronic Nonspecific Low-Back Pain. J Strength Cond Res, 23(2), 513-523. https://doi.org/10.1519/jsc.0b013e3181918a6e

Knutzen, K. M., Pendergrast, B. A., Lindsey, B., B., \& Brilla, L. R. (2007). The effect of high resistance weight training on reported pain in older adults. J Sci Med Sport, 6(4), 455-460.

Koltyn, K. F. (2002). Exercise-Induced Hypoalgesia and Intensity of Exercise. Sports Med, 32(8), $477-$ 487. https://doi.org/10.2165/00007256-200232080-00001

Koltyn, K. F., \& Arbogast, R. W. (1998). Perception of pain after resistance exercise. Br J Sports Med, 32(1), 20-24. https://doi.org/10.1136/bjsm.32.1.20

Kraemer, W. J., Häkkinen, K., Newton, R. U., Nindl, B. C., Volek, J. S., McCormick, M., Gotshalk, L. A., Gordon, S. E., Fleck, S. J., Campbell, W. W., Putukian, M., \& Evans, W. J. (1999). Effects of heavyresistance training on hormonal response patterns in younger vs. older men. J Appl Physiol, 87(3), 982-992. https://doi.org/10.1152/jappl.1999.87.3.982

Lemmer, J. T., Martel, G. F., Hurlbut, D. E., \& Hurley, B. F. (2007). Age and Sex Differentially Affect Regional Changes in One Repetition Maximum Strength. J Strength Cond Res, 21(3), 731. https://doi.org/10.1519/r-20816.1

Liu-Ambrose, T. Y. L., Khan, K. M., Eng, J. J., Lord, S. R., Lentle, B., \& McKay, H. A. (2005). Both resistance and agility training reduce back pain and improve health-related quality of life in older women with low bone mass. Osteoporos Int, 16(11), 1321-1329. https://doi.org/10.1007/s00198-005$\underline{1842-3}$

Maher, C. (2004). Effective physical treatment for chronic low back pain. Orthop Clin North Am, 35(1), 57-64. https://doi.org/10.1016/s0030-5898(03)00088-9

Malmivaara, A., Häkkinen, U., Aro, T., Heinrichs, M. L., Koskenniemi, L., Kuosma, E., Lappi, S., Paloheimo, R., Servo, C., Vaaranen, V., \& Hernberg, S. (1995). The Treatment of Acute Low Back Pain - Bed Rest, Exercises, or Ordinary Activity? N Engl J Med, 332(6), 351-355. https://doi.org/10.1056/nejm199502093320602

Marcell, T. J. (2003). Review Article: Sarcopenia: Causes, Consequences, and Preventions. J Gerontol A Biol Sci Med Sci, 58(10), M911-M916. https://doi.org/10.1093/gerona/58.10.m911

Maul, I., Läubli, T., Oliveri, M., \& Krueger, H. (2005). Long-term effects of supervised physical training in secondary prevention of low back pain. Eur Spine J, 14(6), 599-611. https://doi.org/10.1007/s00586004-0873-3

Moher, D. (2009). Preferred Reporting Items for Systematic Reviews and Meta-Analyses: The PRISMA Statement. Ann Intern Med, 151(4), 264. https://doi.org/10.7326/0003-4819-151-4-20090818000135

Moritani, T., \& deVries, H. A., H. A. (1979). Neural factors versus hypertrophy in the time course of muscle strength gain. Am J Phys Med Rehabil, 58(3), 115- 130.

Moseley, G. L., \& Hodges, P. W. (2005). Are the Changes in Postural Control Associated With Low Back Pain Caused by Pain Interference? Clin J Pain, 21(4), 323-329. https://doi.org/10.1097/01.ajp.0000131414.84596.99

Mutubuki, E. N., Beljon, Y., Maas, E. T., Huygen, F. J. P. M., Ostelo, R. W. J. G., van Tulder, M. W., \& van Dongen, J. M. (2019). The longitudinal relationships between pain severity and disability versus health-related quality of life and costs among chronic low back pain patients. Qual Life Res, 29(1), 275-287. https://doi.org/10.1007/s11136-019-02302-w 
Nelson, M. E., Rejeski, W. J., Blair, S. N., Duncan, P. W., Judge, J. O., \& King, A. C. (2007). Physical Activity and Public Health in Older Adults. Circulation, 116(9), 1094-1105. https://doi.org/10.1161/circulationaha.107.185650

Reid, M. C., Williams, C. S., \& Gill, T. M. (2005). Back Pain and Decline in Lower Extremity Physical Function Among Community-Dwelling Older Persons. J Gerontol A Biol Sci Med Sci, 60(6), 793-797. https://doi.org/10.1093/gerona/60.6.793

Schild von Spannenberg, S., Jones, G. T., \& Macfarlane, G. J. (2012). The evidence base for managing older persons with low back pain. $\mathrm{Br} J$ Pain, 6(4), 166-169. https://doi.org/10.1177/2049463712466323

Shiri, R., Karppinen, J., Leino-Arjas, P., Solovieva, S., \& Viikari-Juntura, E. (2009). The Association Between Obesity and Low Back Pain: A Meta-Analysis. Am J Epidemiol, 171(2), 135-154. https://doi.org/10.1093/aje/kwp356

Simmons, V., \& Hansen, P. D. (1996). Effectiveness of Water Exercise on Postural Mobility in the Well Elderly: An Experimental Study on Balance Enhancement. The Journals of Gerontology Series A: Biological Sciences and Medical Sciences, 51A(5), M233-M238. https://doi.org/10.1093/gerona/51a.5.m233

Singh, M. A. F. (2002). Exercise Comes of Age: Rationale and Recommendations for a Geriatric Exercise Prescription. J Gerontol A Biol Sci Med Sci, 57(5), M262-M282. https://doi.org/10.1093/gerona/57.5.m262

Smith, D., Bissell, G., Bruce-Low, S., \& Wakefield, C. (2011). The effect of lumbar extension training with and without pelvic stabilization on lumbar strength and low back pain1. J Back Musculoskelet Rehabil, 24(4), 241-249. https://doi.org/10.3233/bmr-2011-0301

Spennewyn, K. C. (2008). Strength Outcomes in Fixed Versus Free-Form Resistance Equipment. J Strength Cond Res 22(1), 75-81. https://doi.org/10.1519/jsc.0b013e31815ef5e7

Standaert, C. J. (2008). Low Back Pain in the Adolescent Athlete. Phys Med Rehabil Clin N Am, 19(2), 287-304. https://doi.org/10.1016/i.pmr.2008.01.002

Taylor, J. B., Goode, A. P., George, S. Z., \& Cook, C. E. (2014). Incidence and risk factors for first-time incident low back pain: a systematic review and meta-analysis. Spine J, 14(10), 2299-2319. https://doi.org/10.1016/i.spinee.2014.01.026

Tsui, S. L., Chen, P. P., \& Ng, K. F. J. (2010). Pain Medicine: A Multidisciplinary Approach (1.a ed.). Hong Kong University Press.

Ugur, M., Derouiche, L., \& Massotte, D. (2018). Heteromerization Modulates mu Opioid Receptor Functional Properties in vivo. Front Pharmacol, 9, 1240. https://doi.org/10.3389/fphar.2018.01240

Urquhart, D. M., Berry, P., Wluka, A. E., Strauss, B. J., Wang, Y., Proietto, J., Jones, G., Dixon, J. B., \& Cicuttini, F. M. (2011). 2011 Young Investigator Award Winner. Spine, 36(16), 1320-1325. https://doi.org/10.1097/brs.0b013e3181f9fb66

Vadalà, G., Russo, F., De Salvatore, S., Cortina, G., Albo, E., Papalia, R., \& Denaro, V. (2020). Physical Activity for the Treatment of Chronic Low Back Pain in Elderly Patients: A Systematic Review. Clin Med, 9(4), 1023. https://doi.org/10.3390/jcm9041023

Verna, J. L., Mayer, J. M., Mooney, V., Pierra, E. A., Robertson, V. L., \& Graves, J. E. (2002). Back Extension Endurance and Strength. Spine, 27(16), 1772-1777. https://doi.org/10.1097/00007632$200208150-00016$

Vincent, H. K., George, S. Z., Seay, A. N., Vincent, K. R., \& Hurley, R. W. (2014a). Resistance Exercise, Disability, and Pain Catastrophizing in Obese Adults with Back Pain. Med Sci Sports Exerc, 46(9), 1693-1701. https://doi.org/10.1249/mss.0000000000000294 
Vincent, H. K., Vincent, K. R., Seay, A. N., Conrad, B. P., Hurley, R. W., \& George, S. Z. (2014b). Back Strength Predicts Walking Improvement in Obese, Older Adults with Chronic Low Back Pain. PM R, 6(5), 418-426. https://doi.org/10.1016/..pmri.2013.11.002

World Health Organization (2016). Acción multisectorial para un envejecimiento sano basado en el ciclo de vida: proyecto de estrategia y plan de acción mundiales sobre el envejecimiento y la salud. 69. ${ }^{a}$ ASAMBLEA MUNDIAL DE LA SALUD. Punto 13.4 del orden del día provisional (p. A69/17). Ginebra: OMS. Retrieved from http://apps.who.int/gb/ebwha/pdf_files/WHA69/A69_17-sp.pdf

\section{(c) (1) (9)}

This work is licensed under a Attribution-NonCommercial-NoDerivatives 4.0 International (CC BY-NC-ND 4.0). 